\title{
Impact of air-conditioning system disinfection on microbial contamination of passenger cars
}

\author{
Małgorzata Gołofit-Szymczak ${ }^{1}$ (D) - Agata Stobnicka-Kupiec ${ }^{1} \cdot$ Rafał L. Górny ${ }^{1}$
}

Received: 27 March 2019 / Accepted: 30 July 2019 /Published online: 9 August 2019

(C) The Author(s) 2019

\begin{abstract}
An automobile air-conditioning (AC) system can be a source of microbiological contamination in a driver's car. The aim of this study was to assess the level of microbial contamination before and after servicing of the automobile AC system, based on qualitative and quantitative analyses of bacteria and fungi isolated from the air, and to check the efficiency of different AC system cleaning methods in the removal of microbial contaminants. The study was carried out in 35 randomly selected cars, equipped with AC systems. In each car tested, viable bioaerosol samples were taken using a single-stage MAS impactor before and after servicing the AC systems. Four methods were used to disinfect the air-conditioning installations in the vehicles examined: ozonisation, application of chemical disinfectant using ultrasounds, manual application of chemical disinfectant foam and simultaneous ozonisation and application of chemical disinfectant foam. The bacterial and fungal concentrations in air samples before AC servicing in cars were between $7.5 \times 10^{1} \mathrm{cfu} / \mathrm{m}^{3}$ and $2.0 \times 10^{3} \mathrm{cfu} / \mathrm{m}^{3}$ and $4.0 \times 10^{1} \mathrm{cfu} / \mathrm{m}^{3}$ and $5.0 \times 10^{2} \mathrm{cfu} / \mathrm{m}^{3}$, respectively. Regardless of the disinfection method, after the AC service, a decrease in microbial concentrations was observed. The highest disinfection efficiency was observed for two methods: ozonisation combined with manual application of the chemical disinfectant into the air-conditioning system and spraying of the chemical disinfectant using ultrasounds.

On the basis of the results obtained, it can be concluded that air-conditioning systems in cars should be regularly disinfected to eliminate microbiological contaminants, which may be the cause of adverse health effects on humans.
\end{abstract}

Keywords Air-conditioning $\cdot$ Contamination $\cdot$ Bacteria $\cdot$ Fungi $\cdot$ Cars

\section{Introduction}

The total number of cars in the world in 2015 was 947 million passenger cars and 335 million commercial vehicles. There are 256 million passenger cars registered in Europe alone. Each year, the number of cars is increasing and it is projected that it will reach 2 billion by around 2030. These numbers also make the automotive sector very important to the global economy. For example, about 12.6 million people, i.e. $5.7 \%$ of European Union workers, are employed in this sector (European Vehicle Market Statistics 2016).

Electronic supplementary material The online version of this article (https://doi.org/10.1007/s11869-019-00731-7) contains supplementary material, which is available to authorized users.

Małgorzata Gołofit-Szymczak magol@ciop.pl

1 Laboratory of Biohazard, Department of Chemical, Aerosol and Biological Hazard, Central Institute for Labour Protection-National Research Institute, Czerniakowska 16 Str., 00-701 Warsaw, Poland
Cars are our number one source of mobility, and road transport is the most common means of transport in the world. Over $70 \%$ of journeys around the world are private car or taxi journeys. Every day, thousands of people spend many hours in different types of road transport vehicles (e.g. private cars, taxis, buses or trucks). Professional drivers (e.g. taxi and truck drivers) spend on average about $8 \mathrm{~h}$ a day in their vehicles (Holmer et al. 1995; Jo and Lee 2008; Vonberg et al. 2010; Wu et al. 2016).

To improve our travel comfort, cars are equipped with air-conditioning (AC) installations. The first airconditioning system installed into a vehicle took place in 1933 in the USA. Since then, an increase in the number of cars equipped with $\mathrm{AC}$ systems has been systematically observed. Cars equipped with an $\mathrm{AC}$ system accounted for less than $50 \%$ of these produced before the year 2000 , while this percentage is significantly higher among new models (in 2013 it was already $74 \%$ ).

The main task of an automotive AC system is to ensure the appropriate quality of the air inside the car. The most important air parameters, which can be regulated in the air-conditioned interior, are temperature and 
relative humidity. A well-functioning air-conditioning system guarantees driver and passenger comfort by, for example, providing cold air during the summer, as well as protection from particle pollution of the atmospheric air. The use of an AC system also usually results in a decrease in the presence of microbial contaminants inside the vehicle (Vonberg et al. 2010; Lee and Jo 2005; Li et al. 2013). In practice, modern automotive airconditioning installations become quite often an active source of emission of harmful biological agents (mainly bacteria and fungi). This development of microbes is a result of surface contamination of the AC system, strongly supported by the increase in air humidity caused by the small diameter of air-conditioning cords, air cleaners, air refrigerators etc. Some microbial contaminants are able to easily create a biofilm in the airconditioning ducts and as such can be distributed around the other installation elements, as well as within the car interior itself (Simmons et al. 1997, 1999).

The longer the automotive AC installation is used, the more likely it will become a source of adverse air pollution of microbial origin in the car cabin.

Exposure to bioaerosols may lead to adverse health effects, ranging from simple irritations, through allergic reactions, to infectious diseases or toxic response (Douwes et al. 2003; Flannigan and Miller 1994; Sykes et al. 2007; Jodeh et al. 2018). Numerous studies prove that exposure to high concentrations of microorganisms in the air is often linked to asthma, rhinitis and pneumonia. Bioaerosols might also present a risk to human health since they can be a source of harmful structures and substances exhibiting immunological reactivity (allergens, mycotoxins, endotoxins and other microbial cell fragments) in the air (Fiegel et al. 2006; Kumar et al. 1984).

Proper servicing of automotive air-conditioning installations requires systematic maintenance. It is advised to regularly replace the cabin filters, clean and disinfect the air ducts, evaporator and air inlets of the motor-car body and control the permeability of the condensation extracting canal from the airconditioning installation evaporator.

Various methods are used to clean air-conditioning installations: chemical (use of disinfectants), physical (ozonisation) and chemicophysical (use of disinfectants combined with ultrasounds). Regular cleaning of air-conditioning installations significantly influences the maintenance process and, therefore, the indoor air quality.

The aim of this study was to assess the level of microbial contamination before and after servicing of the automobile $\mathrm{AC}$ system, based on qualitative and quantitative analyses of bacteria and fungi isolated from the air, and to check the efficiency of different AC system cleaning methods in the removal of microbial contaminants.

\section{Methods}

\section{Characteristics of disinfection methods for automotive air-conditioning systems}

In all of the vehicles examined, the tightness of the airconditioning installation was checked, the coolant level was inspected and topped up, cabin filters were replaced and the dehumidifier and evaporator were inspected before the specific disinfection method was applied.

Four methods were used to disinfect the AC installations in the vehicles examined:

1. Ozonisation, involving the application of concentrated ozone $(14 \mathrm{~g} / \mathrm{h})$ in the vehicle cab, starting the engine and turning on the air-conditioner in a closed cycle mode. The ozonisation process ran for $20 \mathrm{~min}$ in every car, and after approx. 15-20 min, the vehicles were ventilated. An ozone generator was used for ozonisation.

2. Application of a chemical disinfectant containing 2propanol (1-2.5\%) inside the vehicle cab using ultrasounds; after $30 \mathrm{~min}$ of disinfection, the vehicles were ventilated for $15 \mathrm{~min}$.

3. Manual application (spraying chemical disinfectant containing 2-propanol, in a foam form (50-70\%)) through the air inlets in the dashboard for $30 \mathrm{~min}$.

4. Ozonisation combined with the application of a chemical disinfectant foam.

\section{Car characteristics}

Thirty-five randomly selected vehicles equipped with airconditioning systems were examined and divided into 4 groups, including the vehicles with $\mathrm{AC}$ systems that were disinfected with ozone $(1 / \mathrm{O}-10 / \mathrm{O})$, ultrasonically distributed chemical disinfectant $(1 / \mathrm{U}-10 / \mathrm{U})$, with manually distributed chemical disinfectant $(1 / \mathrm{CH}-10 / \mathrm{CH})$ and using a combination of two methods, i.e. ozonisation and manual application of disinfectant $(1 / \mathrm{O} / \mathrm{CH}-5 / \mathrm{O} / \mathrm{CH})$.

The examined vehicles had two types of AC systems installed:

- Manual single-zone air-conditioner, controlled directly by the driver; the temperature regulation was performed by mixing hot air (from the air heater) with cold air; the driver was unable to precisely set the temperature inside the car.

- Automatic air-conditioner, controlled by an electronic system using readings from the car sensors (e.g. external and internal temperature sensors, solar sensor); depending on the internal conditions, the ventilation is usually pointed either on the windscreen, side windows or the legs; to avoid installation overload, $20 \%$ of the air comes from 
the outside and the rest comes from a closed cycle (socalled recirculation); the automatic AC systems were equipped with a multisegment heater that provided both the driver and passenger with climate control (dual and four-zone) (26).

During the experiments, the indoor temperature was set for $23{ }^{\circ} \mathrm{C}$ in all of the vehicles examined.

Detailed characteristics of the examined vehicles are provided as supplemental documentation (Table S1).

\section{Sampling strategies}

Air samples were collected before and after disinfection of the AC systems in the cars under study. At the same time, in order to determine 'outdoor background', the atmospheric bioaerosol was collected outside the car cabin.

The viable (understood here as culturable) bioaerosol samples were taken using a single-stage MAS impactor (model 100 Eco, Merck, Germany). The flow rates, as well as sampling times, were $100 \mathrm{~L} / \mathrm{min}$ and $1.5 \mathrm{~min}$, respectively.

During the tests, the impactor was placed within a zone of about $0.5 \mathrm{~m}$ from the vent/supply air outlets located next to the steering wheel, and at a height of $1 \mathrm{~m}$ above the car's floor, to simulate aspiration from the human breathing zone of the car driver/passenger.

\section{Colony counting and microbiological analyses}

Air samples were collected on agar media. Standard Petri dishes filled with blood trypticase soy agar (TSA, 51044, bioMérieux, France) and malt extract agar (MEA, CM-59, Oxoid Ltd., Great Britain) were used for bacterial and fungal sampling, respectively. The collected samples were incubated as follows: bacteria- 1 day at $37{ }^{\circ} \mathrm{C}$, followed by 3 days at $22{ }^{\circ} \mathrm{C}$ and 3 days at $4{ }^{\circ} \mathrm{C}$; fungi- 4 days at $30^{\circ} \mathrm{C}$ followed by 4 days at $22^{\circ} \mathrm{C}$ (Jensen and Schafer 1998). After incubation, the concentrations of viable microorganisms in the air were calculated as colony-forming units per cubic metre of the air $\left(\mathrm{cfu} / \mathrm{m}^{3}\right)$.

\section{Taxonomical identification of isolated microorganisms}

Species identification was carried out using microscopic and biochemical methods.

The taxonomical origin of isolated pathogens was additionally confirmed using molecular techniques.

\section{Conventional methodologies}

At the beginning, the bacteria were identified by Gram staining (111885 Gram-color stain set; Merck KgaA, Germany) (Murray et al. 2013) to determine their morphology and, finally, by the biochemical analytical profile index (API) tests (bioMérieux, France). Yeast strains were identified by the API (API $20 \mathrm{C}$ Aux) test. Filamentous fungi were initially stained with lactophenol and subsequently identified according to their morphology using several identification keys (Fisher and Cook 1998; Samson et al. 2004; St-Germain and Summerbell 2011).

\section{Molecular methodologies}

Bacterial species identification Bacterial DNA was isolated from pure cultures which were grown on TSS plates (trypticase soy agar $+5 \%$ sheep blood) using a Qiamp DNA Mini Kit (Qiagen, Hilden, Germany), according to the manufacturer's instructions. DNA isolation included preincubation with lysozyme and lysostaphin. The isolated DNA was used as a template in PCR reaction with the following primers set: BAK11w (5'-AGTTTGATCMTGGCTCAG-3') and BAK2 (5'-GGACTACHAGGGTATCTAAT-3'), which enable the amplification of bacterial 16S rRNA gene fragment corresponding to $E$. coli $16 \mathrm{~S}$ rRNA gene positions from 10 to 806. The amplified PCR product was purified and sequenced using an ABI3730 Genetic Analyser (Applied Biosystems, Waltham, USA). The sequence was compared with the GenBank database (National Center for Biotechnology Information, U.S. National Library of Medicine, USA) using a BLAST algorithm (Basic Local Alignment Search Tool) (Bosshard et al. 2003; Bosshard et al. 2006).

Fungal species identification Fungal DNA was isolated from pure cultures which were grown on MEA plates (malt extract agar), using a Fungi DNA Mini Kit (Syngen Biotech, Wrocław, Poland), following the manufacturer's instructions. The isolated DNA was used as a template in PCR reaction using an ITS1 (5'-TCCGTAGGTGAACCTGCGG-3') and ITS4 (5'-TCCTCCGCTTATTGATATGC-3') primer set which enables the amplification of the ITS (internal transcribed spacer) region of the nuclear ribosomal DNA (rDNA) repeat. The amplified PCR products were purified, sequenced using an ABI3730 Genetic Analyzer (Applied Biosystems) and compared with the GenBank database (National Center for Biotechnology Information) using a BLAST algorithm (Basic Local Alignment Search Tool) (White et al. 1990).

\section{Measurement of microclimate parameters}

The environmental conditions (temperature and relative humidity of the air) in the cars under study and outside in the exterior were checked during every sampling session using hythergraph (Omniport 20, E+E Elektronik $\mathrm{GmbH}$, Austria). 


\section{Statistical analysis}

The measurement obtained data were statistically processed, on the basis of the Kruskal-Wallis, Wilcoxon and MannWhitney tests, as well as Spearman's correlation analysis using the 'STATISTICA data analysis software system' package, version 7.1 (StatSoft, Inc., USA). The $p$ values below 0.05 were adopted as statistically significant.

\section{Results}

\section{Quantitative analysis of bacterial and fungal aerosols}

The mean concentrations of bacterial and fungal aerosols measured using the MAS impactor in the studied cars and in outdoor background (in the air outside the cars) are presented in Table 1.

Data from this study showed that the observed concentrations of airborne microbiota were low and did not exceed $2 \times$ $10^{3} \mathrm{cfu} / \mathrm{m}^{3}$.

The present study revealed statistically significant differences in concentrations of microorganisms between tested cars (Kruskal-Wallis test $(p<0.001)$ ). The lowest concentrations of bioaerosols were observed in the $5 / \mathrm{O}$ car. This vehicle was the newest vehicle with the lowest number of kilometres travelled (demo car in a dealer's showroom). The highest concentrations of bioaerosols were recorded in the $1 / \mathrm{O} / \mathrm{CH}$ car, i.e. in the vehicle with the highest mileage.

Using the Spearman correlation coefficient with the impact of the mileage, the type of air-conditioning system (1-, 2-, 4zone and manual), type of car body (SUV, sedan, estate) and type of upholstery (fabric, leather) for concentrations of microorganisms in the air of the tested vehicles were evaluated. The results revealed that the mileage significantly determined the observed concentrations of bacterial and fungal aerosols $(R=0.71$ at $p<0.001)$. Along with the high number of kilometres travelled, an increase in the concentration of bacterial fungal aerosols in the studied vehicles was observed before the air-conditioning service. There was also a significant effect of the body car type on the concentration of bacteria in the air of the tested vehicles $(p<0.05)$. SUVs have lower bacterial concentrations than sedans and estate cars. No such differences were observed in the concentration of fungi.

It was also found that the type of AC system and the type of upholstery did not significantly determine the observed concentrations of bacterial and fungal aerosols in the tested vehicles.

Independent from the applied disinfection method, the concentrations of bacterial and fungal aerosols measured in cars before the service of the vehicle AC system were significantly higher than those in cars after an AC service (Wilcoxon test $(p<0.001))$.
The use of ozone as a disinfectant resulted in an average reduction of bacterial and fungal aerosol concentrations of $45.8 \%$ and $42.7 \%$, respectively. The distribution of chemical disinfectant in the car cabin using ultrasounds resulted in a decrease in the bacterial aerosol concentrations of about $76 \%$ and fungal aerosol concentrations of about $77 \%$. In turn, the manual application of a chemical disinfectant in the AC systems of the tested cars resulted in an average decrease in bacterial and fungal aerosol concentrations of $30.8 \%$ and $42.2 \%$, respectively. The use of the ozonisation method combined with the manual application of a chemical disinfectant was the most effective in $\mathrm{AC}$ system cleaning, reducing the bacterial and fungal aerosol concentrations in car cabins by $80.8 \%$ and by $61.9 \%$, respectively.

Bacterial concentrations in outdoor background were significantly lower (except in cars after an ultrasound service) than those observed in cars before the service of the vehicle air-conditioning system $(p<0.01)$. In turn, fungal outdoor background levels were significantly higher than those observed in the studied cars before and after the service $(p<0.01)$.

Microclimate parameters did not significantly determine the observed bioaerosol concentrations in all the tested cars. This demonstrates that mechanical separation of microbial particles is more important for the prevention of a car cabin's contamination than microclimate conditions provided by an AC system.

\section{Qualitative analysis of bacterial and fungal aerosols}

All bacterial and fungal strains isolated from the air of examined cars are provided as supplemental documentation (Table S2 and S3).

A total number of 28 bacterial species belonging to 10 genera and 31 fungal species from 18 genera were identified in the air of car cabins before the AC service. Qualitative analysis demonstrated that the most prevalent bacterial species in all the cars studied were Gram-positive cocci (mainly from Staphylococcus and Micrococcus/ Kocuria genera) and endospore-forming Gram-positive rods (from Bacillus genus). Among the most common fungal species were those from Penicillium, Aspergillus and Cladosporium genera.

Using the classifications of harmful biological agents included in Directive 2000/54/EC and Ordinance of Polish Minister of Health, it was ascertained that in the air of car cabins before the AC service, there are species and genera of microorganisms classified into risk group 2: Bacillus subtilis, Bacillus thuringiensis, Corynebacterium spp., Aspergillus fumigatus and Penicillium spp. (microorganisms can cause disease in humans, but the disease is treatable or preventable). In car cabins where manual 
Table 1 Bacterial and fungal concentrations in the studied cars before and after servicing of the vehicle air-conditioning systems. SD - standard deviation

\begin{tabular}{llll}
\hline Sample type & Bacterial concentrations $\left(\mathrm{cfu} / \mathrm{m}^{3}\right) \pm \mathrm{SD}$ & & Fungal concentrations $\left(\mathrm{cfu} / \mathrm{m}^{3}\right) \pm \mathrm{SD}$ \\
\cline { 2 - 3 } & Before AC service After AC service & Before AC service $\quad$ After AC service
\end{tabular}

\begin{tabular}{ccccc}
\hline $\begin{array}{c}\text { Ozonisation } \\
\text { 1/O }\end{array}$ & & & \\
2/O & $270 \pm 14.1$ & $115 \pm 7.1$ & $120 \pm 28.2$ & $65 \pm 7.1$ \\
$3 / \mathrm{O}$ & $510 \pm 42.4$ & $275 \pm 77.8$ & $195 \pm 7.1$ & $115 \pm 21.2$ \\
$4 / \mathrm{O}$ & $300 \pm 14.1$ & $150 \pm 56.6$ & $185 \pm 7.1$ & $90 \pm 14.1$ \\
$5 / \mathrm{O}$ & $375 \pm 91.9$ & $170 \pm 42.4$ & $160 \pm 28.0$ & $80 \pm 14.1$ \\
$6 / \mathrm{O}$ & $75 \pm 21.2$ & $40 \pm 14.1$ & $40 \pm 28.3$ & $20 \pm 14.1$ \\
$7 / \mathrm{O}$ & $810 \pm 287.0$ & $260 \pm 28.2$ & $80 \pm 28.0$ & $25 \pm 7.0$ \\
$8 / \mathrm{O}$ & $990 \pm 98.8$ & $600 \pm 21.2$ & $505 \pm 49.4$ & $320 \pm 7.0$ \\
$9 / \mathrm{O}$ & $790 \pm 254.5$ & $580 \pm 212.1$ & $175 \pm 35.3$ & $125 \pm 35.3$ \\
$10 / \mathrm{O}$ & $495 \pm 91.2$ & $305 \pm 63.6$ & $230 \pm 42.4$ & $175 \pm 35.3$ \\
Ap & $320 \pm 42.4$ & $220 \pm 28.3$ & $160 \pm 14.1$ & $110 \pm 28.1$
\end{tabular}

Application of a chemical disinfectant substance inside the vehicle cab using ultrasounds

\begin{tabular}{|c|c|c|c|c|}
\hline $1 / U$ & $280+1033$ & & $105+71$ & $25+71$ \\
\hline $2 / \mathrm{U}$ & $580 \pm 42.4$ & $95 \pm 7.1$ & $165 \pm 21.2$ & $35 \pm 7.1$ \\
\hline $3 / \mathrm{U}$ & $818 \pm 120.2$ & $140 \pm 14.1$ & $295 \pm 106.1$ & $50 \pm 7.1$ \\
\hline $4 / U$ & $310 \pm 84.8$ & $120 \pm 14.1$ & $115 \pm 21.2$ & $40 \pm 28.3$ \\
\hline $5 / \mathrm{U}$ & $965 \pm 148.4$ & $165 \pm 7.1$ & $285 \pm 120.2$ & $70 \pm 14.1$ \\
\hline $6 / U$ & $585 \pm 120.2$ & $140 \pm 0$ & $225 \pm 49.5$ & $65 \pm 7.1$ \\
\hline $7 / \mathrm{U}$ & $430 \pm 84.8$ & $115 \pm 35.3$ & $170 \pm 42.4$ & $55 \pm 21.2$ \\
\hline $8 / \mathrm{U}$ & $205 \pm 21.2$ & $65 \pm 21.2$ & $105 \pm 7.1$ & $25 \pm 7.1$ \\
\hline $9 / \mathrm{U}$ & $835 \pm 233.3$ & $145 \pm 21.2$ & $315 \pm 77.8$ & $75 \pm 35.3$ \\
\hline $10 / U$ & $610 \pm 84.8$ & $120 \pm 42.4$ & $170 \pm 1.5$ & $25 \pm 14.1$ \\
\hline \multicolumn{5}{|c|}{ Chemical disinfectant foam } \\
\hline $1 / \mathrm{CH}$ & $900 \pm 424.2$ & $780 \pm 98.9$ & $90 \pm 113.1$ & $25 \pm 21.1$ \\
\hline $2 / \mathrm{CH}$ & $670 \pm 84.8$ & $430 \pm 0$ & $125 \pm 35.3$ & $115 \pm 21.2$ \\
\hline $3 / \mathrm{CH}$ & $230 \pm 28.3$ & $150 \pm 56.5$ & $385 \pm 21.2$ & $155 \pm 7.1$ \\
\hline $4 / \mathrm{CH}$ & $305 \pm 35.3$ & $115 \pm 7.1$ & $215 \pm 35.3$ & $70 \pm 14.1$ \\
\hline $5 / \mathrm{CH}$ & $120 \pm 42.4$ & $120 \pm 28.2$ & $90 \pm 42.4$ & $50 \pm 0$ \\
\hline $6 / \mathrm{CH}$ & $170 \pm 28.3$ & $140 \pm 0$ & $105 \pm 7.1$ & $75 \pm 21.2$ \\
\hline $7 / \mathrm{CH}$ & $290 \pm 42.4$ & $185 \pm 21.1$ & $180 \pm 14.1$ & $125 \pm 35.3$ \\
\hline $8 / \mathrm{CH}$ & $460 \pm 42.4$ & $310 \pm 14.1$ & $250 \pm 14.1$ & $185 \pm 7.1$ \\
\hline $9 / \mathrm{CH}$ & $640 \pm 42.4$ & $410 \pm 28.2$ & $175 \pm 35.3$ & $150 \pm 0$ \\
\hline $10 / \mathrm{CH}$ & $940 \pm 380.1$ & $570 \pm 28.2$ & $155 \pm 63.6$ & $45 \pm 7.1$ \\
\hline \multicolumn{5}{|c|}{ Ozonisation and application of a chemical disinfectant foam } \\
\hline $1 / \mathrm{O} / \mathrm{CH}$ & $2025 \pm 63.3$ & $555 \pm 7.1$ & $415 \pm 63.3$ & $165 \pm 21.1$ \\
\hline $2 / \mathrm{O} / \mathrm{CH}$ & $800 \pm 98.9$ & $295 \pm 35.3$ & $320 \pm 42.4$ & $100 \pm 0$ \\
\hline $3 / \mathrm{O} / \mathrm{CH}$ & $1800 \pm 565.6$ & $290 \pm 42.4$ & $435 \pm 49.4$ & $185 \pm 7.1$ \\
\hline $4 / \mathrm{O} / \mathrm{CH}$ & $985 \pm 120.2$ & $330 \pm 14.1$ & $275 \pm 63.6$ & $120 \pm 28.3$ \\
\hline $5 / \mathrm{O} / \mathrm{CH}$ & $1045 \pm 346.5$ & $200 \pm 0$ & $420 \pm 98.9$ & $160 \pm 14.1$ \\
\hline Outdoor background & $187 \pm 14.8$ & & $290 \pm 56.6$ & \\
\hline
\end{tabular}

application of a chemical disinfectant foam was performed as simultaneous ozonisation and application of a chemical disinfectant foam, Aspergillus fumigates were not detected. No presence of Bacillus subtilis was found in the cars under study after an AC service.
Each of the tested AC service methods decreased the taxonomical diversity of the car cabin microbiota. Only 16 bacterial species from 6 genera and 13 fungal species from 11 genera were identified in car cabins after ozonisation. In the car cabins after disinfectant application with ultrasounds, 17 
bacterial species from 7 genera and 15 fungal species from 9 genera were identified. A total number of 19 bacterial species from 8 genera and 15 fungal species from 8 genera were identified in car cabins after chemical (foam) service of the $\mathrm{AC}$ systems. The samples taken after the AC service by means of chemical and ozonisation methods presented 19 species of bacteria from 8 genera and 15 species of fungi from 8 genera.

The percentage shares of particular groups of bacteria and fungi in relation to the whole microbiota identified in the studied cars are presented in Fig. 1.

The most numerous groups of microorganisms in the air of the car cabins were Gram-positive cocci (from 40 to $54 \%$ ), followed by filamentous fungi (from 20 to $33 \%$ ) and endospore-forming Gram-positive bacilli (from 20 to 29\%). Yeasts, nonsporing Gram-positive rods and actinomycetes were the smallest fractions of identified microorganisms in studied cars. The species composition of airborne microbiota in cars before the AC service was similar to that observed in cars after the AC service, except of actinomycetes, which were not detected after $\mathrm{AC}$ service using ozonisation and a chemical disinfectant.

Qualitative structure of microbiota in car cabins differed substantially from the microbial composition of the outdoor air, where a domination of filamentous fungi (68\%) was clearly visible.

\section{Discussion}

Cars are nowadays by far the most common means of transport. People spend a great deal of time in them, so the quality of their indoor air is of great importance to health.

According to the literature, the use of an AC system usually decreases bioaerosol concentrations inside the vehicle. Sowiak et al. (2018) found that operating an AC system makes it possible to decrease fungal microbiota by $68-78 \%$. Similar findings were observed by Wang et al. (2013) and Vonberg et al. (2010), studying bacterial and fungal spores after the airconditioning or ventilation was turned on.
However, the abovementioned findings indicate that the $\mathrm{AC}$ systems or cabin filters may be contaminated with these microorganisms, and their extended use may result in an increase in microbial concentrations inside the driver's car. An AC system which has been improperly maintained (long-term operation of filters or lack of systematic disinfection) may be a source of additional unwanted contamination of the air in cars. As already shown, a constant accumulation of various contaminants (e.g. on filter membranes or as a biofilm on vehicle evaporator surface) contributes to higher concentrations of microorganisms in the car cabin (Lee and Jo 2005; Simmons et al. 1997, 1999).

On the basis of the results of our study, it can be concluded that all four methods of servicing of automotive airconditioning systems were efficient in the reduction of microbial contamination of the air inside the vehicle cabins. The most prominent purification effect was observed for two methods, namely ozonisation combined with the application of a chemical disinfectant foam and spraying of a chemical disinfectant using ultrasounds. Ozone has welldocumented antibacterial properties and can be used to inactivate a wide range of microorganisms, including viruses and bacteria, which can be resistant to other disinfectants (Kim et al. 1999). As indicated by Sharna and Hudson (2008), ozone also has bactericidal properties against MRSA strains. Ozone is usually applied to eliminate odours and to reduce and/or remove microorganisms from both air and surfaces in hospital rooms and ventilation ducts in buildings (EPA 1997). This gas can effectively penetrate the hard-to-reach areas of air-conditioning ducts and all other indoor spaces, making it possible to achieve a very high level of disinfection (Otter et al. 2009; Sharna and Hudson 2008; Zoutman et al. 2011). However, as a highly reactive gas, ozone levels should never exceed the level of $0.15 \mathrm{mg} / \mathrm{m}^{3}$ for an 8 -h exposure.

Biocides used for the disinfection of air-conditioning systems usually contain 2-propanol (isopropyl alcohol), i.e. a substance with a wide spectrum of antiviral, bactericidal and
Fig. 1 Percentage distributions of microbial groups in the air of the studied car cabins

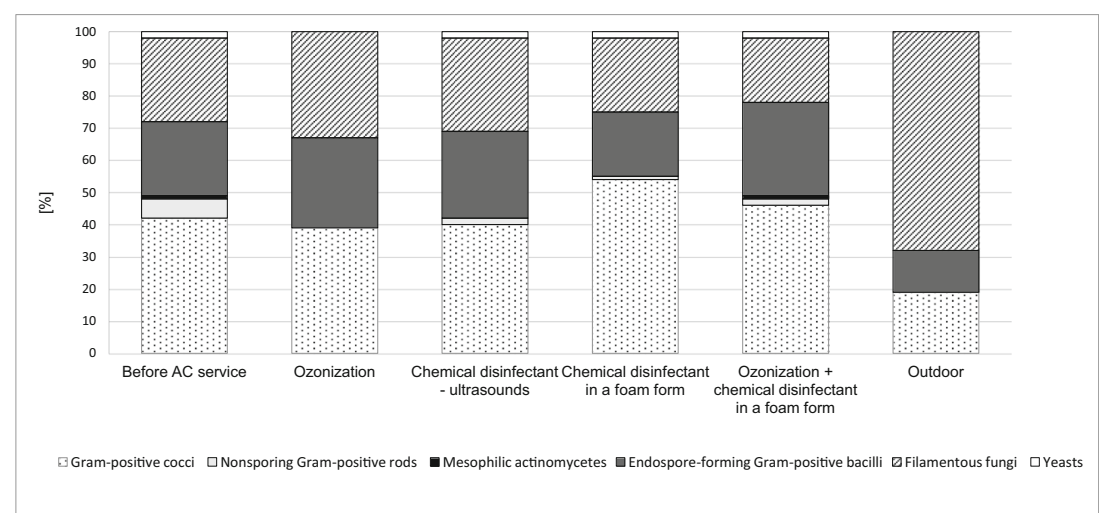


fungicidal activity. As already shown, 2-propanol is more effective against Staphylococcus aureus and Escherichia coli than ethanol (Burcea et al. 2013). It is easily available, so it is most widely used for ventilation duct cleaning and as a disinfectant in healthcare. Alcohols are most effective when mixed with purified water. This form facilitates their diffusion through the cell membranes of microorganisms. The optimal antimicrobial effect of isopropyl alcohol is in the range of 60 to $90 \%$ (McDonnell and Denver Russell 1999; Sultan et al. 2012). The 2-propanol-based chemical disinfectant, when introduced through the vehicle's dashboard, is not always evenly distributed across all components of the car's airconditioning system. Therefore, this process should be mechanically supported by, for example a source of ultrasounds.

The device used in our study produces high-frequency ultrasounds $(1.7 \mathrm{~Hz})$, spraying the aerosol disinfectant. This spraying of the disinfectant, through the inlet and outlet ducts (air and ventilation) of the vehicle, reaches the evaporator of the air-conditioner and cleans all the components of the air-conditioning system in cars. The use of ultrasound to spray the disinfectant in the studied cars was very effective and resulted in a decrease in the microbiological concentration by over $70 \%$.

Air-conditioning service engineers using this type of product must have experience and knowledge of the construction of ventilation systems in various vehicle brands.

Many studies have documented the presence of many types of harmful biological agents in the air in vehicles (Aquino et al. 2018; Lee and Jo 2005; Li et al. 2013; Simmons et al. 1999; Sowiak et al. 2018; Viegas et al. 2018). The current airborne microorganism concentrations inside the studied cars were found to be similar to those published in other reports (Lee and Jo 2005; Li et al. 2013; Nowakowicz-Dębek et al. 2017; Simmons et al. 1999).

The air of the studied cars before the AC service contained bacterial and fungal species belonging to risk group 2; according to European Directive 2000/54, the following were identified: Bacillus subtilis, Bacillus thuringiensis, Corynebacterium spp. and Aspergillus fumigatus. This means that car drivers and passengers may be exposed to direct contact with biological agents that are occupational hazards and which are potentially pathogenic.

The cars tested were contaminated with allergenic fungal species (Aspergillus spp., Penicillium spp., Cladosporium spp. and Alternaria spp.). The same fungal genera of fungi were isolated from the air inside the vehicles by NowakowiczDębek et al. (2017), Jo and Lee (2008), Sowiak et al. (2018) and Viegas et al. (2018). Fungi and their by-products, such as (1-3)- $\beta$-D-glucan, mycotoxins and microbial volatile organic compounds (MVOCs), have been implicated in adverse health reactions and diseases. Expert reviews of reported health problems associated with biological agents concluded, on the basis of many epidemiological studies, that human exposure to high levels of fungal aerosols can result in a variety of adverse health outcomes including respiratory, haematological, immunological and neurological system disorders and/or diseases (Gołofit-Szymczak and Górny 2018, Rylander et al. 2008). The presence of fungi in high concentrations can cause the appearance of allergic reactions and various nonspecific adverse health outcomes such as sick building syndrome (SBS). The moulds of Alternaria, Aspergillus, Cladosporium, Fusarium, Rhizopus and Penicillium species are associated with allergy and respiratory problems (Aquino et al. 2018; Jones et al. 2011; Hwang and Cho 2016; Stephenson et al. 2014; Kumar et al. 1990; Rylander et al. 2008).

On the basis of the results obtained, it can be concluded that air-conditioning systems in cars should be regularly disinfected to eliminate bacterial and fungal contaminants that may be the cause of adverse health effects on humans.

\section{Conclusions}

- The tested methods of servicing automotive airconditioning systems in the cars studied work so efficiently to cause a reduction of microbial contamination of the air inside the vehicle cabin. The highest disinfection efficiency was observed for ozonisation combined with the manual application of a chemical disinfectant into the car air-conditioning system and spraying a chemical disinfectant using ultrasounds.

- The qualitative analysis of the air microbiota in the cars studied indicated the presence of bacterial and fungal microorganisms which, according to the Ordinance of the Minister of Health, are classified into risk group 2. Direct contact with those microorganisms may cause adverse health effects for drivers and passengers alike.

- The most prevalent bacterial species in the air of car cabins were Gram-positive cocci (mainly from Staphylococcus and Micrococcus/Kocuria genera) and endosporeforming Gram-positive rods from Bacillus genus. Among the most common fungal representatives were those from the Alternaria, Aspergillus, Cladosporium and Penicillium genera.

- Vehicle air-conditioning systems should be systematically maintained. The whole system should be regularly disinfected to eliminate microbiological contaminants.

Acknowledgements This paper has been based on the results of a research task carried out within the scope of the fourth stage of the National Programme "Improvement of safety and working conditions" partly supported in 2017-2019 - within the scope of state services - by the Ministry of Labour and Social Policy. The Central Institute for Labour Protection-National Research Institute is the programme's main coordinator. 
Open Access This article is distributed under the terms of the Creative Commons Attribution 4.0 International License (http:// creativecommons.org/licenses/by/4.0/), which permits unrestricted use, distribution, and reproduction in any medium, provided you give appropriate credit to the original author(s) and the source, provide a link to the Creative Commons license, and indicate if changes were made.

\section{References}

Aquino S, Lima JEA, Nascimento APB, Reis FC (2018) Analysis of fungal contamination in vehicle air filters and their impact as a bioaccumulator on indoor air quality. Air Qual Atmos Health 11(10):1143-1153. https://doi.org/10.1007/s11869-018-0614-0

Bosshard PP, Kronenberg A, Zbinden R, RuefC, Böttger EC, Altwegg M (2003) Etiologic diagnosis of infective endocarditis by broad-range polymerase chain reaction: a 3-year experience. Clin Infect Dis 37(2):167-172. https://doi.org/10.1086/375592

Bosshard PP, Zbinden R, Abels S, Böddinghaus B, Altwegg M, Böttger EC (2006) 16S rRNA gene sequencing versus the API 20 NE system and the VITEK 2 ID-GNB card for identification of nonfermenting Gram-negative bacteria in the clinical laboratory. J Clin Microbiol 44(4):1359-1366. https://doi.org/10.1128/JCM.44. 4.1359-1366.2006

Burcea CC, Armen P, Burlibasa L, Popa M, Ionescu I, Cernausca-Mitariu M (2013) Alcohols and phenols:theoretical and practical aspects related to their use in medical practice. Metal Int 18(8):261-264

Directive 2000/54/EC of the European Parliament and of the Council of 18 September 2000 on the protection of workers from risks related to exposure to biological agents at work. Off J Eur Union L 2000; 262/21:21-45

Douwes J, Thorne P, Pearce N, Heederik D (2003) Bioaerosol health effects and exposure assessment: progress and prospects. Ann Occup Hyg 47:187-200. https://doi.org/10.1093/annhyg/meg032

EPA (1997) Should you have the air ducts in your home cleaned? EPA402-K-97-002. Research Triangle Park: U.S. Environmental Protection Agency Indoor Environment Division, Office of Air and Radiation

European Vehicle Market Statistics. Pocketbook 2015/16 (2016) International Council on Clean Transportation Europe, Berlin

Fiegel J, Clarke R, Edwards DA (2006) Airborne infectious disease and the suppression of pulmonary bioaerosols. Drug Discov Today 11: 51-57. https://doi.org/10.1016/S1359-6446(05)03687-1

Fisher F, Cook NB (1998) Fundamentals of diagnostic mycology. WB Saunders Company, Philadelphia

Flannigan B, Miller JD (1994) Health implications of fungi in indoor environments - an overview. In: Samson RA, Flannigan ME, Verhoeff AP, Adan OCG, Hoekstra ES (eds) Health implications of fungi in indoor environments. Elsevier, Amsterdam

Gołofit-Szymczak M, Górny RL (2018) Microbiological air quality in office buildings equipped with dventilation systems. Indoor Air 28(6):792-805

Holmer I, Nilsson H, Bohm M, Noren O (1995) Thermal aspects of vehicle comfort. Appl Hum Sci 14:159-165

Hwang SH, Cho JH (2016) Evaluation of airborne fungi and the effects of a platform screen door and station depth in 25 underground subway stations in Seoul, South Korea. Air Qual Atmos Health 9(561):561568. https://doi.org/10.1007/s11869-015-0361-4

Jensen PA, Schafer MP (1998) Sampling and characterization of bioaerosols. NIOSH Manual of Analitical Methods

Jo WK, Lee JH (2008) Airborne fungal and bacterial levels associated with the use of automobile air conditioners or heaters, room air conditioners, and humidifiers. Arch Environ Occup Health 63(3): 101-107. https://doi.org/10.3200/AEOH.63.3.101-107

Jodeh S, Hasan AR, Amarah J, Judeh F, Salghi R, Lgaz H, Jodeh W (2018) Indoor and outdoor air quality analysis for the city of Nablus in Palestine: seasonal trends of PM10, PM5.0, PM2.5, and PM1.0 of residential homes. Air Qual Atmos Health 11(2):229-237. https://doi.org/10.1007/s11869-017-0533-5

Jones R, Recer GM, Hwang SA, Lin S (2011) Association between indoor mold and asthma among children in Buffalo, New York. Indoor Air 21:156-164. https://doi.org/10.1111/j.1600-0668.2010.00692.x

Kim JG, Yousef AE, Dave S (1999) Application of ozone for enhancing the microbiological safety and quality of foods: a review. J Food Prot 62:1071-1087

Kumar P, Marier R, Leech SH (1984) Respiratory allergies related to automobile air conditioners. N Engl J Med 311:1619-1621. https://doi.org/10.1056/NEJM198412203112507

Kumar P, Lopez M, Fan W, Cambre K, Elston RC (1990) Mold contamination of automobile air conditioner system. Ann Allergy Asthma Immunol 64:174-177

Lee JH, Jo WK (2005) Exposure to airborne fungi and bacteria while commuting in passenger cars and public buses. Atmos Environ 39: 7342-7350. https://doi.org/10.1016/j.atmosenv.2005.09.013

Li JL, Mingzhen S, Fangxia ZZ, Yao M, Wu CY (2013) Characterization of biological aerosol exposure risks from automobile air conditioning system. Environ Sci Technol 47:10660-10666. https://doi.org/ 10.1021/es402848d

McDonnell G, Denver Russell A (1999) Antiseptical and disinfectants: activity, action, and resistance. Clin Microbiol Rev 12(1):147-179

Murray PR, Rosenthal KS, Pfaller MA (2013) Medical microbiology, 7th edn. Elsevier Saunders, Philadelphia

Nowakowicz-Dębek B, Pawlak H, Wlazło Ł, Maksym P, Kapica J, Chmielowiec-Korzeniowska A, Trawińska B (2017) Evaluating bioaerosol exposure among bus drivers in the public transport sector. J Occup Environ Hyg 14(11):D169-D172. https://doi.org/10.1080/ 15459624.2017.1339165

Ordinance of the Minister of Health of April 22, 2005, on hazardous biological agents in the work environment and the protection of health of workers occupationally exposed to them. J Laws 2005;81:716

Otter J, Puchowicz M, Ryan D, Salkeld JA, Cooper TA, Havill NL, Tuozzo K, Boyce JM (2009) Feasibility of routinely using hydrogen peroxide vapour to decontaminate rooms in a busy United States hospital. Infect Control Hosp Epidemiol 30(6):574-577. https://doi. org $/ 10.1086 / 597544$

Rylander R, Fogelmark B, Ewaldsson B (2008) Moldy environments and toxic pneumonitis. Toxicol Ind Health 24:177-180. https://doi.org/ 10.1177/0748233708093356

Samson RA, Hoekstra ES, Frisvad JC (2004) Introduction to food- and airborne fungi, 7th edn. Centraalbureau voor Schimmelcultures, Utrecht

Sharna M, Hudson JB (2008) Ozone gas is an effective and practical antibacterial agent. Am J Infect Control 36(8):559-563. https://doi. org/10.1016/j.ajic.2007.10.021

Simmons RB, Noble JA, Rose L, Price DL, Ahearn DG (1997) Fungal colonization of automobile air conditioning systems. J Ind Microbiol Biotechnol 19:150-153. https://doi.org/10.1038/sj.jim.2900451

Simmons RB, Rose LJ, Crow SA, Ahearn DG (1999) The occurrence and persistence of mixed biofilms in automobile air conditioning systems. Curr Microbiol 39:141-145

Sowiak M, Kozajda A, Jeżak K, Szadkowka-Stańczyk I (2018) Does the air condition system in busses spread allergic fungi into driver space? Environ Sci Pollut Res 25:5013-5023. https://doi.org/10. 1007/s11356-017-0830-4

Stephenson RE, Gutierrez D, Peters C, Nichols M, Boles BR (2014) Elucidation of bacteria found in car interiors and strategies to reduce 
the presence of potential pathogens. Biofouling 30(3):337-346. https://doi.org/10.1080/08927014.2013.873418

St-Germain G, Summerbell R (2011) Identifying filamentous fungi, 2nd ed. Star, Belmont

Sultan Z, Nilsson G, Magee R (2012) Testing effectiveness of duct cleaning and its impact on airborne particles, mold and biocide levels in commercial office buildings, NCR-CNCR, Canada

Sykes P, Jones K, Wildsmith JD (2007) Managing the potential public health risks from bioaerosol liberation at commercial composting sites in the UK: an analysis of the evidence base. Resour Conserv Recycl 52:410-424. https://doi.org/10.1016/j.resconrec.2007.05.005

Viegas C, Monteiro A, Dos Santos M, Faria T, Caetano LA, Carolino, Quintal Gomes A, Marchand G, Lacombe N, Viegas S (2018) Filters from taxis air conditioning system: a tool to characterize driver's occupational exposure to bioburden? Environ Res 164:522-529. https://doi.org/10.1016/j.envres.2018.03.032

Vonberg RP, Gastmeier P, Kenneweg B, Holdack-Janssen H, Sohr D, Chaberny IF (2010) The microbiological quality of air improver when using air conditioning systems in cars. BMC Infect Dis 10: 146-151. https://doi.org/10.1186/1471-2334-10-146
Wang YF, Tsai CH, Huang YT, Chao HR, Tsou TC, Kuo YM, Wang LC, Chen SH (2013) Size distribution of airborne fungi in vehicles under various driving conditions. Arch Environ Occup Health 68:95-100. https://doi.org/10.1080/19338244.2011.650798

White TJ, Bruns T, Lee S, Tailor S (1990) Amplification and direct sequencing of fungal ribosomal RNA genes for phylogenetics. In: Innins MA, Gelf DH, Sninsky JJ, White TJ (eds) PCR protocols. A guide to methods and applications. Academic Press, Inc, San Diego, pp 315-322

Wu Y, Chen A, Luhung I, Gall ET, Cao Q, Chang VW, Nazaroff WW (2016) Bioaerosol deposition on a $\mathrm{n}$ air-conditioning cooling coil. Atmos Environ 144:257-265. https://doi.org/10.1016/j.atmosenv. 2016.09.004

Zoutman D, Shannon M, Mandel A (2011) Effectiveness of a novel ozone-based system for the rapid high-level disinfection of health care spaces and surfaces. Am J Infect Control 39:873-879. https:// doi.org/10.1016/j.ajic.2011.01.012

Publisher's note Springer Nature remains neutral with regard to jurisdictional claims in published maps and institutional affiliations. 